\title{
THE CONSTITUTIONALITY OF THE LEGAL REGIME OF THE SACRED GOODS FROM THE PERSPECTIVE OF THE LAW NO. 489/2006 REGARDING RELIGIOUS FREEDOM AND THE GENERAL REGIME OF THE CULTS
}

DOI:10.47743/rdc-2020-1-0002

Costică CIOCAN, doctoral student Doctoral School of the Faculty of Law of "Alexandru Ioan Cuza" University of lași

\section{Abstract}

This paper addresses the legal regime of sacred goods from the perspective of the immunity from distraint and of the fact of not being subject to a statute of limitations they enjoy and the way in which granting this protection could conflict with the fundamental law.

Keywords: religious freedom; the general regime of the cults; ownership right; sacred goods

\section{Introduction}

Law No. 489 of December 28, 2006 on religious freedom and the general regime of cults was published in the Official Gazette of Romania, Part I, No. 11 of January 8, 2007, in order to give full effect to S.29 of the Constitution, which protects the individual's intimate beliefs in relation to his religious beliefs.

Thus, the Statement of Reasons of the Chamber of Deputies ${ }^{1}$ shows that: "Although the Church plays a determining role in the Romanian society, constituting a pillar of social solidarity, the normative framework in force regulating the activity of religious cults, respectively the Decree No. 177/1948, as subsequently amended and supplemented, no longer corresponds to the current requirements of the society, many of the provisions being eliminated or becoming inapplicable".

By S.49 of Law No. 489/2006 it was established that the 18 acknowledged cults undertake, within 12 months from the date of entry into force of the law, to present the canonical statutes and codes to the State Secretariat for Cults, for their validation.

1 The document can be accessed on the website of the Chamber of Deputies at http://www.cdep.ro/proiecte/2006/000/20/5/em25.pdf. 


\section{Costică CIOCAN}

In compliance with the legal provisions, the Romanian Orthodox Church has submitted to the Ministry of Culture and Cults its own status of organization and operation $^{2}$, which was recognized by means of the Government Decision No. 53 of January 16, 2008, published in the Official Gazette No. 50 of January 22, 2008. By S.2 of the same act of the Government "The Decree of the Presidium of the Great National Assembly No. 233/1949 for the approval of the Statute for the organization and operation of the Romanian Orthodox Church, unpublished, as subsequently amended" was repealed.

The Statute for the Organization and Operation of the Romanian Orthodox Church (hereinafter Statute), starts with S.1 with the definition of the Church, understood as "community of Orthodox Christians, clerics, monks and laymen, canonically constituted in parishes and monasteries in the dioceses of the Romanian Patriarchate located inside and outside the borders of Romania, who confess God in the Holy Trinity, Father, Son and The Holy Spirit, on the basis of Holy Scripture and Holy Tradition, and participate in the life of the Church through the same Holy Sacraments, liturgical services and canonical customs".

The statute provides the concrete way of organization of the Orthodox Church, both inside and outside the borders of Romania, and includes, among others, rules according to which the church patrimony is administered.

Next, we will analyse the categories of goods that are part of the church patrimony and their special legal regime, related to S. 44 of the Constitution of Romania which establishes the right to private property and to $\mathrm{S} .53$ regarding the restriction of the exercise of certain rights or freedoms.

\section{The patrimony of the cults}

By S.27 of Law No. 489/2006, "The acknowledged cults and their units of cult may also acquire, under ownership or administration, movable and immovable property, which they may dispose of in accordance with their own statutes", by conferring on them the right to participate as subjects of right to civil legal relations.

However, of a real interest there is the second paragraph of S.27 of Law No. $489 / 2006$ which, by defining by means of a general formula the sacred goods, establishes for these goods a special legal regime. Thus, S.27 a. 2 of Law No. 489/2006 stipulates that: "the sacred goods, respectively those directly and exclusively affected by the cult, established according to their own statutes according to the tradition and

\footnotetext{
2 The statute for the organization and operation of the Romanian Orthodox Church can be accessed on the website of the Romanian Patriarchate at: http://patriarhia.ro/images/document/statutul_bor.pdf.
}

CONSTITUTIONAL LAW REVIEW 
The Constitutionality of the legal regime of the sacred goods...

practices of each cult, acquired by title, have immunity from distraint and are not subject to a statute of limitations and can only be sold under the specific statutory conditions of each cult".

The immunity from distraint and the fact of not being subject to a statute of limitations granted by the law to the rights related to the sacred goods cause them to have a special legal regime in the civil circuit, in specific cases, conflicts occurring between the participants in the civil legal relations, precisely because of these effects.

S.170 of the Statute stipulates that the church patrimony consists of sacred and joint goods, showing that sacred goods "are those goods which by sanctification or blessing are intended for divine cult, such as: places of worship (cathedrals, churches, parishes, chapels etc.), church objects and vestments, ritual books, cemeteries etc.".

However, there is also a category of goods assimilated to the sacred goods, with the same legal regime, which include "the parochial house, the parish and monastery hearth, the premises of the Eparchial Centre, of the Patriarchal Centre, the kyriarchal residences, the cells of the monasteries and hermitages, the precious goods, with artistic, historical value or due to the material from which they are made, such as: paintings, sculptures, artistic fabrics, miniatures, rare books, documents, works from expensive materials etc." [S. 170 (4) Statute] ${ }^{3}$.

Regarding the common goods, these are listed as an example in S.170 (6) of the Statute ("the buildings of the church schools, the buildings of the church administrations, the religious museums, the cultural and philanthropic and economic establishments and institutions, the agricultural lands, the forests, the pastures, the vineyards, the orchards, the gardens, the patrimonial rights, the claims, the social shares, the stocks, the funds, the bonds, cash etc.") and are affected by the recurring activities of the Church, as an initiator of social and cultural-religious activities.

This margin of appreciation of the Romanian Orthodox Church, to establish what goods are sacred or not, with the consequence of their immunity from distraint and the fact of not being subject to a statute of limitations, according to S.27 of Law No. 489/2006, was criticized for unconstitutionality from the perspective of S.16 Constitution on equality in rights, of S.44 regarding the right of private property, of S.53 regarding the restriction of rights or freedoms and of $\mathrm{S.73}$ regarding the categories of laws.

${ }^{3}$ I.C. Vardianu, Administrarea bunurilor Bisericii Ortodoxe Române potrivit reglementărilor ecleziale și legislației de stat din secolul al XV-lea și până în prezent (Teză de doctorat)/Administration of the goods/assets of the Romanian Orthodox Church according to the ecclesiastical regulations and the state legislation from the fifteenth century and up to now (Doctoral thesis), Arad, 2018, p. 35.

STUDIES AND ARTICLES 
III. The Decision of the Constitutional Court No. 336/2018 regarding

the rejection of the exception of unconstitutionality of the provisions

of S.27 of Law No. 489/2006 regarding religious freedom

and the general regime of the cults

The origin of the case is a request for court action pending before the dockets of Târgu Neamț District Court, whereby the authors of the exception asked in contradiction with the Agapia Monastery and the administrative-territorial unit of the Agapia Commune, for the court to acknowledge they acquired the right of ownership of a land and building located inside the built-up area of Agapia Commune, Neamț County.

Even if the Constitutional Court held that S.27 of Law No. 489/2006 is not related to the settlement of the case, the Târgu Neamț District Court admitting the request for court action of the authors of the exception and finding that the usucaptio from 10 to 20 years intervened, the critics of the petitioners need to be analysed in this article, being of interest both from a theoretical as well as from a practical perspective.

Thus, they show that by "the criticized legal provisions, which provide that by their own statutes the religious cults can establish what goods are sacred and, as such, immune from distraint and not subject to a statute of limitations, derogations discreetly included in the normative act, from the legal regime of the lands" 4 are made.

Considering the object of the action with which the court was invested (action for finding the acquisition of the ownership right by usucaptio), it can be inferred that the interest of raising the exception of unconstitutionality of S.27 of Law No. 489/2006 could have consisted in excluding the possibility of the court to, by way of interpretation, consider the disputed real estate as sacred goods, immune from distraint and not subject to a statute of limitations, with the consequence of a possible solution to dismiss the action.

In other words, the authors of the exception raise the question regarding the limits of the sacred regarding the legal regime of the goods and whether this restriction of the rights of the other participants who could not acquire such goods by means of usucaptio is reasonable and justified by a public interest.

According to the Decision of the Constitutional Court No. 270 of May 7, 2014, published in the Official Gazette No. 443 of July 28, 2014, "the legislator is entitled to establish the content and limits of the ownership right. In principle, these limits take into account the object of the ownership right and its attributes and are set up for the protection of the general social and economic interests or for the defence of the

4 The decision of the Constitutional Court No. 336/2019 regarding the rejection of the exception of unconstitutionality of the provisions of S.27 of Law No. 489/2006 regarding religious freedom and the general regime of cults can be accessed at: https://lege5.ro.

CONSTITUTIONAL LAW REVIEW 
The Constitutionality of the legal regime of the sacred goods...

fundamental rights and freedoms of other persons, the essential fact being that the ownership right is not completely annihilated".

Therefore, by S.27 of Law No. 489/2006, taking into account the specificity of the goods destined exclusively and directly to the cult, the legislator understood to grant them superior legal protection, as these are immune from distraint and not subject to a statute of limitations.

However, a legal problem could arise when a cult considers as sacred the totality of the goods/assets that it holds in its patrimony, assuring them by this disposition the immunity from distraint and the fact of not being subject to a statute of limitations.

According to the Statute for the Organization and Operation of the Romanian Orthodox Church, we can see an extension of the sacred to a category of goods that, by strictly speaking, exceeds the divine cult, and which benefit from the same legal regime (for example, the parish house, the cells of monasteries etc.).

In research literature", it has been shown that "sacredness concerns everything that has a religious dimension, better said all that belongs, by one way or another to the divine cult", in their materiality the goods "being by themselves neither sacred nor profane".

As long as the religious cults interpret the provisions of S.27 of Law No. 489/2006, regarding the "sacred goods", in the most restrictive sense, their application could not be likely of creating litigious situations in practice.

Regarding the restriction of the rights of the other persons to acquire by the effect of adverse possession the "sacred goods", by Decision No. 587 of November 8, 2005, published in the Official Gazette No. 1159 of December 21, 2005, the Constitutional Court ruled that: "the exercise of a right cannot be absolute, by eliminating any restrictions, inherent in considering the existence of other rights belonging to other holders, to whom the state authority is also obliged to grant protection. In other words, freedom - with the meaning conferred, by the legal framework within the limits of which the valorisation of the law is legitimate - ceases where the freedom of other subjects of law begins".

From this perspective, the point of view of the Neamt County Court- $1^{\text {st }}$ Civil Section could be considered justified since "the legislator's option to remove certain categories of goods from the general civil circuit, to which the sacred goods also belong, within the meaning acknowledged by S.27 of Law No. 489/2003, can be determined by the existence of an objective element that resides precisely in the general public interest of the activities carried out by the cults recognized under the conditions of the law (...)".

${ }^{5}$ L.M. Harosa, Relevanța generală a bunurilor în dreptul canonic. Clasificarea bunurilor bisericești în sens larg/General relevance of goods in canon law. The classification of church goods in a broad sense, in Pandectele Române No. 6/2009, p. 46. 


\section{Costică CIOCAN}

The purpose protected by S.27 of Law No. 489/2006 is limited to those provided by S.53 (1) of the Constitution, namely the protection of public morals, the restriction of the rights of third parties being necessary and proportionate, otherwise one could imagine situations in which for non-payment of debts, places of worship or liturgical objects, these could be auctioned and purchased without any restriction, which, given the current state of the company, would be inconceivable.

S.170 (4) of GD No. 53/2008 regarded from the perspective of an administrative act with normative character was also in the attention of the administrative litigation courts. Thus, by Sentence No. 64/2014, the Bacau Court of Appeal vested with an action for partial annulment of GD No. 53/2008 ordered the cancellation of S. 170 (4) of this normative act on the grounds that "The inclusion in the category of sacred property of any immovable property of the parish hearth is illegal"6.

Starting from a strict interpretation of the notion of sacred good, the administrative litigation court criticizes the way in which the Romanian Patriarchate understood to draw up its own Statute, showing that "the Government of Romania had to censor the content of S. 170 (4) of GD No. 53/2008, as long as S.27 (2) of Law No. 489/2006 made it clear that sacred goods can only be considered those which are directly and exclusively destined to the cult".

The arguments of the Bacau Court of Appeal are convincing in relation to the rule of logical interpretation exceptio est strictissimae interpretationis - "in the present case it is found that, although S. 27 of Law No. 489/2006 showed, as a delimitation criterion, that sacred goods are only those directly and exclusively destined to the cult, however through S.170 (4) of GD No. 53/2008 the parochial and monastic establishments notions that include, in the opinion of the Romanian Patriarchate and of the Agaia Monastery the lands that are owned or were owned by the Romanian Orthodox church and its units of cult in the territory were assimilated to these sacred goods".

However, being appealed to the High Court of Cassation and Justice, sentence No. 64/2014 of the Bacau Court of Appeal was quashed by Decision No. 360/20167, holding the compliance of S.170 paragraph (4) of GD No. 53/2008 with S.27 (2) of Law No. 489/2006.

The main argument of the High Court of Cassation and Justice was based on the autonomy of the religious cults and on the right of their appreciation to establish what goods are sacred or not, a right which cannot be censured.

This decision of the High Court of Cassation and Justice aimed at clarifying the legal status of assimilated sacred goods maintained unfortunately the state of uncertainty at the level of the courts, putting them in a position to demonstrate why some goods could not be considered sacred.

${ }^{6}$ Sentence No. 64/2014 of the Bacau Court of Appeal can be accessed at: http://www.rolii.ro.

${ }^{7}$ Decision No. 360/2016 of the High Court of Cassation and Justice, the Administrative and Fiscal Litigation Department can be accessed at: https://www.scj.ro.

\section{CONSTITUTIONAL LAW REVIEW}


The Constitutionality of the legal regime of the sacred goods...

The considerations of the administrative litigation court set out by Sentence No. $64 / 2014$, to which I agree, are not to be neglected, as it expresses in a convincing way that a the civil circuit in which the security of the legal relations regarding goods overrides cannot be created by having a discretionary power of appreciation of any of its subjects.

\section{Conclusions}

Analysing S.27 of Law No. 489/2006, related to S.44 and S.53 of the Constitution of Romania, it can be seen that it respects the constitutional requirements, as long as it is interpreted in the strictest way, considering the role played by the effects of immunity from distraint and of the fact of not being subject to a statute of limitations in the civil legal circuit.

From a comparative perspective, in relation to the Code of Canon Law of the Roman Catholic Church and the Code of the Canons of the Eastern Churches ${ }^{8}$, acknowledged by means of the Government Decision No. 1218 of October 1, 2008, published in the Official Gazette No. 798 bis of November 27, 2008, we can observe different approaches regarding the incidence of limitation.

Thus, Can. 1540 - (according to 197) states that: "The Church admits limitation as a way to acquire or lose a subjective right, as well as to be waived from obligations, as it is the case in civil law, unless otherwise provided in common law", only a certain category of rights being subject to limitation in accordance with Can. 1542 - (= 199), for example: rights and obligations which are of divine law; rights that can only be obtained through apostolic privilege; the safe and uncertain limits of the church constituencies etc.

With regard to sacred goods, according to Can. 1269, it can be found that these can exist under the ownership of private persons and can be acquired by limitation by other private persons, being forbidden to use them for profane purposes unless the dedication or blessing has been lost.

Considering the current social context and the moment of the adoption of Law No. $489 / 2006$ regarding the religious freedom and the general regime of the cults (the publication in the Official Gazette taking place on January 8,2007 ), it is not excluded that in the future, in accordance with the social realities and the dynamics of the civil circuit, the legislator will adopt different solutions in regarding the legal regime of the goods that are in the patrimony of the cults.

\footnotetext{
${ }^{8}$ The Code of Canon Law of the Roman Catholic Church and the Code of Canons of the Oriental Churches can be accessed on the website of the State Secretariat for Cults: http://culte.gov.ro.
}

STUDIES AND ARTICLES 